\title{
Variation in development and growth rates of larval and juvenile spider crabs Hyas araneus reared in the laboratory
}

\author{
Monika Kunisch and Klaus Anger \\ Biologische Anstalt Helgoland (Meeresstation), D-2192 Helgoland, Federal Republic of Germany
}

\begin{abstract}
Statistically significant differences were found in development duration of Hyas araneus $\mathrm{L}$. larvae hatching on different days from the same egg batch. Larvae from different females show a decreasing trend in development time the later they hatch during the season. This trend was found in all larval instars; it was particularly apparent in the megalopa. Development durations in the 2 zoeal stages are positively correlated with each other, i.e. individuals developing slower than the average in the first larval instar tend to delay moulting also in the second instar. There are negative correlations between larval development time in all stages and the size of juvenile crabs, i.e. weak individuals tend to develop more slowly and to become smaller juveniles than the average. These larvae show lower accumulation rates of biomass (measured as dry weight, carbon, and nitrogen) already during the first zoeal stage. Larval development rates (at $12{ }^{\circ} \mathrm{C}$ ) were not clearly affected by the temperature prevailing during previous embryonic development, but embryos incubated at higher temperatures tended to become smaller crabs. Further correlations suggest that crabs (instar I) developing slower than the average will show prolonged intermoult periods also in later instars, and they will have smaller body size throughout their juvenile life. Relative growth rates (percentage gain of carapace length) remain fairly constant (ca. 20 to $25 \%$ per moult). Absolute variation in body size increases from instar to instar. It is partly compensated by differential mortality being higher in the smallest and largest individuals of a population
\end{abstract}

\section{INTRODUCTION}

Rates of development (moulting frequency) and growth (biomass accumulation) have been studied in a number of larval decapod crustaceans (for recent reviews see Anger and Dawirs, 1982; Anger et al., 1983; Dawirs, 1983). It is generally accepted that these rates vary in relation to environmental conditions, e.g. to varying nutrition, temperature, salinity, or water quality. Many of such effects have been described in the literature, but only very little is known about natural variation ('background noise') superimposed to all this environmentally induced variation.

Differences in energy reserves were found between hermit crab larvae (Pagurus bernhardus) hatching in spring and summer (Pandian and Schumann, 1967; Dawirs, 1981). Similar differences were detected in spider crab larvae (Hyas araneus) by Anger and Dawirs (1982). Seasonal variation in development rates of crab larvae reared under constant environmental conditions were observed by Wilson (1980) in
Euchirograpsus americanus, and by Dawirs (1979) in Pagurus bernhardus, and (1982a) in Carcinus maenas. In larvae of Cancer irroratus, Sastry et al. (1977) observed differential mortality and salinity tolerance related to the season of hatching.

Besides seasonal there is genetic variation between different hatches: Dawirs (1982a) reports significant differences in the duration of zoeal development of Carcinus maenas. Lang and Young (1977) reported on variation in hermit crab (Clibanarius vittatus) development, when hatches from the same season (July), but from different years were compared.

There is also evidence for variation within a single hatch: Pandian (1970) found decreasing energy and increasing dry weight in lobster larvae (Homarus americanus) hatching during subsequent nights. Similar observations were made in Macrobrachium idae (Pandian and Katre, 1972).

The present investigation analyses patterns of variation in development and growth rates of larval and juvenile Hyas araneus. As all larvae were reared indi- 
vidually under identical conditions in the laboratory, statistical interrelations between larval and juvenile growth patterns could be considered in this study.

\section{MATERIALS AND METHODS}

Ovigerous females of Hyas araneus were dredged during December, 1980 and 1981, from ca. 30 to $50 \mathrm{~m}$ depth near Helgoland (German Bight, North Sea). They were maintained in the laboratory at $2^{\circ} \mathrm{C}$, in 1981 also at 'ambient' temperatures, 6 and $12{ }^{\circ} \mathrm{C}$, in order to test possible effects of temperature during late embryonic development on larval and postlarval growth and survival. 'Ambient' temperatures averaged ca. $4{ }^{\circ} \mathrm{C}$. In this case, temperature was changed in steps of $1 \mathrm{C}^{\circ}$ to simulate natural conditions near Helgoland (for details see Anger, 1983),

Larvae hatched from February through April. They were collected in flow-through systems and pipetted individually into rearing vials with ca. $25 \mathrm{ml}$ of filtered seawater (ca. $32 \%$ S). Larvae were fed a mixture of freshly hatched Artemia sp. nauplii (San Francisco Bay Brand) and Brachionus plicatilis (ratio ca. 1: 10, ca. 50 to 100 organisms $\mathrm{ml}^{-1}$ ) every second day, after each water change (for more details see Anger and Dawirs, 1981; Dawirs, 1982b). Rearing temperature was $12^{\circ} \mathrm{C}$ in all experiments. Each experimental group comprised 25 or 50 individually reared larvae (1980 and 1981, respectively).

Larvae which reached the megalopa stage were transferred to net-bottom (mesh size: $300 \mu \mathrm{m}$ ) tubules as described by Dawirs (1982b); 50 tubules (inner diameter: $1.6 \mathrm{~cm}$; total length: $7 \mathrm{~cm}$; partly filled with sea water: $5 \mathrm{~cm} \hat{=} 10 \mathrm{ml}$ ) were suspended in 1 tray with 191 filtered seawater, each sticking in a hole drilled in the PVC cover lid. They were moved up with the lid once every day to change the water body inside the tubules; Artemia nauplii were added subsequently. Every week the whole content of the tray was replaced by freshly filtered seawater. This rearing technique had been found particularly efficient because it reduced the working effort and increased the survival of megalopae (Dawirs and Anger, unpubl.).

After metamorphosis, juvenile crabs remained in the net-bottom tubules until they reached the crab II stage. Then they were maintained in compartmented plastic boxes $(5 \times 3.5 \times 3.5 \mathrm{~cm}$ compartment size), where bottom and cover were replaced by nylon gauze (mesh size $1 \mathrm{~mm}$ ). The boxes were submerged in trays connected to a recirculating system. Crabs were fed juvenile Artemia sp. (San Francisco Bay Brand, raised with Dunaliella tertiolecta) whose body size approximately corresponded to the carapace length of the crabs.
Larvae and juveniles were checked daily for mortality and exuviae. Carapace length in dead crabs and exuviae was measured under a stereo microscope by means of an eyepiece micrometer, from the tip of the rostrum to the rear margin of the carapace.

Dry weight and elemental composition (carbon, nitrogen) were measured as described by Anger and Dawirs (1982). Hydrogen values are not considered in the present study, as many data were lost due to a failure of the analyzer. Energy equivalents were estimated using the $\mathrm{N}$-corrected conversion given by Salonen et al. (1976). At least 10 replicate samples were analysed for each value given in Table 2. Statistical procedures employed were the same as those referred to by Anger and Dawirs (1981).

\section{RESULTS}

\section{Variation in larval development and mortality within} 1 hatch

A single female Hyas araneus carries at least 10,000 eggs (Schriever, 1976). The larvae are released from the egg mass over an extended period of ca. 2 to $3 \mathrm{wk}$. Four rearing experiments were conducted in February, 1980 , to test whether there are differences in the viability of larvae hatching on different days from the same female (Table 1): the duration of the zoea I stage was significantly shorter in larvae hatching during the first $2 \mathrm{~d}$ of larval release than in those hatching later (after 13 or $20 \mathrm{~d}$ ). Zoea II exhibited an opposite tendency (statistically not significant).

Although individual variation was greatest in the duration of the megalopa stage, a significant negative

Table 1. Hyas araneus. Duration of larval development $(\mathrm{D}=$ days): mean $(\bar{x}) \pm 95 \%$ confidence intervals and range. Cumulative mortality $(\mathrm{M}=\%)$. All larvae originating from the same hatch

\begin{tabular}{|c|c|c|c|c|c|c|c|c|}
\hline \multirow{2}{*}{$\begin{array}{c}\text { Day of } \\
\text { hatching }\end{array}$} & & \multicolumn{2}{|c|}{ Zoea I } & \multicolumn{2}{|c|}{ Zoea II } & \multicolumn{2}{|c|}{ Megalopa } & \multirow[b]{2}{*}{$\Sigma D$} \\
\hline & & D & $M$ & D & $\mathrm{M}$ & $\mathrm{D}$ & $M$ & \\
\hline \multirow{3}{*}{1} & $\bar{x}$ & 11.8 & 4 & 15.1 & 8 & 29.0 & 12 & 55.8 \\
\hline & \pm & 0.1 & & 0.6 & & 1.6 & & 2.0 \\
\hline & Range & $10-14$ & & $13-19$ & & $23-38$ & & $47-67$ \\
\hline \multirow{3}{*}{2} & $\bar{x}$ & 12.0 & 0 & 15.0 & 0 & 28.8 & 12 & 55.4 \\
\hline & \pm & 0.3 & & 0.5 & & 1.5 & & 1.4 \\
\hline & Range & $11-15$ & & $13-17$ & & $22-35$ & & $51-60$ \\
\hline \multirow{3}{*}{13} & $\overline{\mathrm{x}}$ & 13.1 & 4 & 14.9 & 8 & 27.8 & 28 & 55.6 \\
\hline & \pm & 0.4 & & 0.7 & & 1.5 & & 2.0 \\
\hline & Range & $12-15$ & & $12-18$ & & $23-44$ & & $49-74$ \\
\hline \multirow{3}{*}{20} & $\overline{\mathrm{x}}$ & 12.9 & 8 & 14.1 & 16 & 26.6 & 36 & 53.6 \\
\hline & \pm & 0.4 & & 0.7 & & 1.8 & & 1.9 \\
\hline & Range & $12-15$ & & $12-16$ & & $20-33$ & & $45-58$ \\
\hline
\end{tabular}


correlation was found between day of hatching and mean time of megalopa development ( $\mathrm{r}=-0.989$; $\mathrm{P}=$ 0.01). Total larval development from hatching to metamorphosis varied considerably (45 to $74 \mathrm{~d}$ ), without showing a clear tendency in relation to the day of hatching.

Since these significant differences in development rates of zoea I and megalopa stages occurred within 1 hatch, and mortality increased in later hatching larvae (Table 1), only zoeae hatching within a few days after the onset of larval release were used in later experiments.

\section{Variation in development and mortality of larvae and juveniles from different hatches}

During the same hatching season (1980) larvae from different hatches were reared. Development and mortality rates in relation to time (calendar day) of hatching are given in Fig. 1. Duration of development revealed a decreasing trend during the season in all larval stages. This tendency was statistically significant in the megalopa instar and in total larval develop-

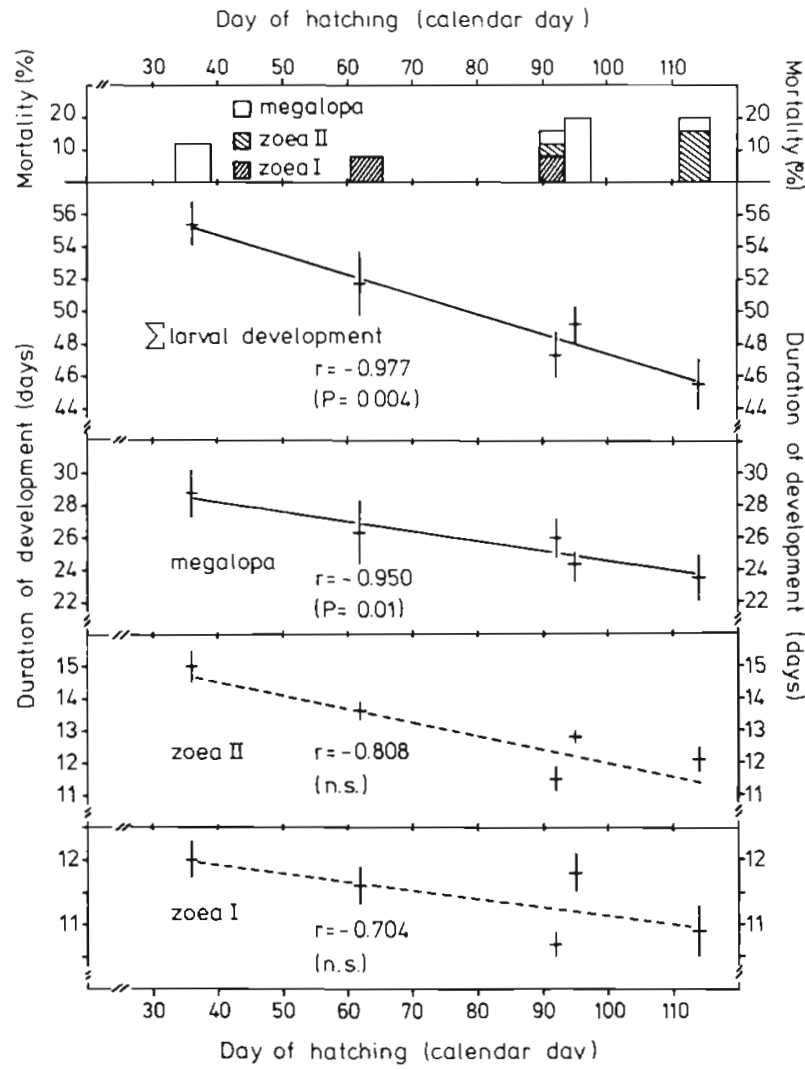

Fig. 1. Hyas araneus. Larval development (mean $\pm 95 \%$ confidence intervals) and mortality in relation to day of hatching. Correlation coefficient, $r_{i}$ level of significance, $P ; n . s .=$ not significant $(\mathrm{P}>0.05)$ ment from hatching to metamorphosis. Mortality during this time amounted to $20 \%$ or less in all larval groups without showing any clear trend.

Similar tendencies were found in 3 rearing experiments (hatches from February 5, March 3, and April 5, 1980) carried out at $18^{\circ} \mathrm{C}$ : zoea I development was constant; it lasted $8.1 \pm 0.1,8.2 \pm 0.3$, and $8.2 \pm 0.2 \mathrm{~d}$, respectively (mean $\pm 95 \%$ confidence intervals). Zoea II duration, however, showed a clearly decreasing trend: $10.2 \pm 0.5,8.4 \pm 0.6$, and $8.2 \pm 0.3 \mathrm{~d}$, respectively. Unfortunately, mortality at $18^{\circ} \mathrm{C}$ was very high, particularly in the megalopa stage. Only 1 larva of the second hatch and 2 of the third one reached metamophosis to the crab. Also here, decreasing development times of the megalopa could be observed: 22,21 , and $18 \mathrm{~d}$. The same holds true for the period of total larval development: 40, 37, and $34 \mathrm{~d}$.

The duration (D) of the first 3 crab stages also tended to decrease in relation to the time of hatching (d). This relationship could be described statistically by nonlinear regression equations ( $D=a+b d+c d^{2}$; Fig. 2). At the end of the hatching season there was no further decrease in $D$, but rather a slight increase or no significant change at all.

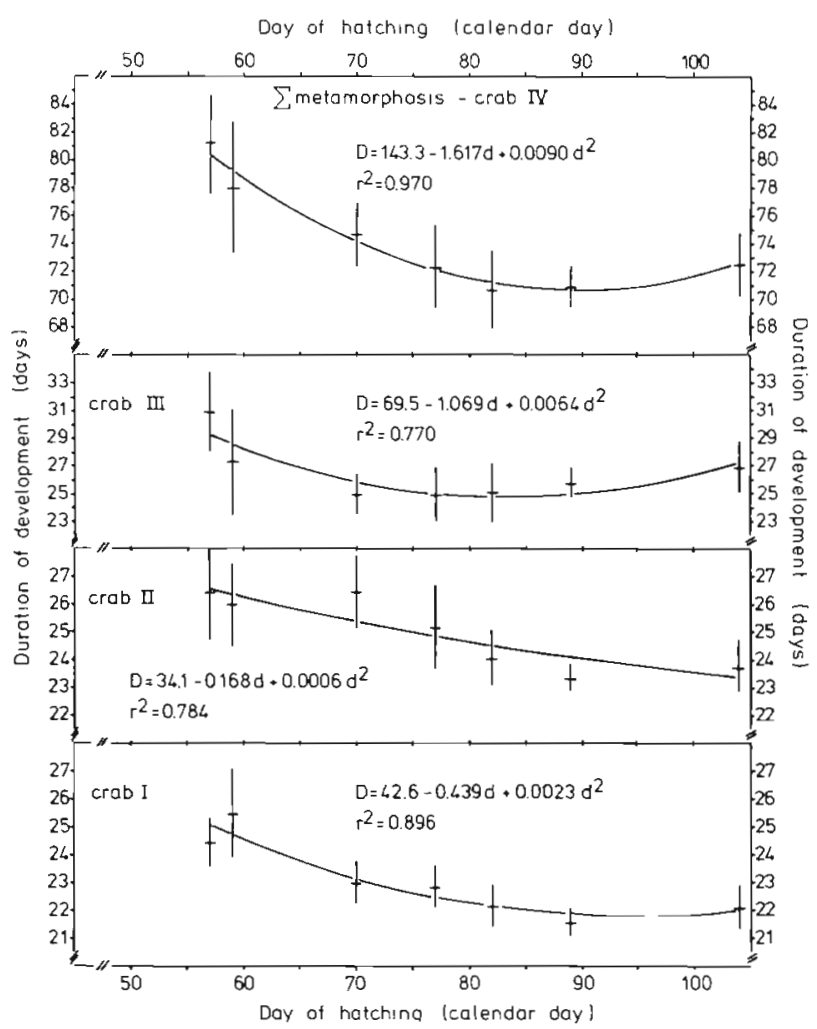

Fig. 2. Hyas araneus. Postlarval development (D, mean $\pm 95 \%$ confidence intervals) in relation to day of hatching (d). Coefficient of determination, $\mathrm{r}^{2}$ 


\section{Interrelations between development times in different instars of individual larvae and juveniles}

Statistical analysis of the numerous data obtained in 1981 revealed that instar durations of the 2 zoeal stages are positively correlated with each other $(\mathrm{r}=0.25 ; \mathrm{n}=$ 380; $\left.\mathrm{P}<10^{-6}\right)$. In other words: larvae developing particularly slow or fast (i.e. deviating from the average) in the zoea I stage tend to show similar deviations also in the next zoeal stage. There is no significant correlation, however, between the duration of either zoea I or II with the megalopa stage $(r=0.02$ and 0.06 , respectively).

Similar as in the zoeal stages, there is also a significant positive correlation between the durations of subsequent crab stages (instars I to III) $\mathrm{r}=0.305 ; \mathrm{n}=313$; $\left.\mathrm{P}<10^{-7}\right)$. No significant relations between larval and juvenile development rates were found.

\section{Variation in larval growth rate}

Larval growth rates (defined as accumulation of biomass per unit of time) were estimated only in the first zoeal stage. Table 2 shows dry weight, carbon, nitrogen, and energy determined in freshly hatched larvae and in those approaching ecdysis $110 \mathrm{~d}$ after hatching). There is only relatively little variation in the initial values and no trend in relation to previous temperature or to the time of hatching, but there are considerable differences in late premoult zoeae.

Since growth patterns of biomass (y) in relation to larval age $(x)$ can be described by the general equation $y=b \cdot x^{m}$ (Anger and Dawirs; 1982), the parameter $m$ may be used as an index of growth rate. Fig. 3 shows this coefficient, as an example estimated for the energy gain (y) during the first $10 \mathrm{~d}$ of larval life $\left(\mathrm{m}_{10}\right)$. For calculation, $b$ was assumed to equal the antilogarithm $\left(e^{b}\right)$ of initial energy (Anger and Dawirs, 1982). Fig. 3 suggests that initial growth rates are higher in larvae hatching later in the season. The temperature regimen

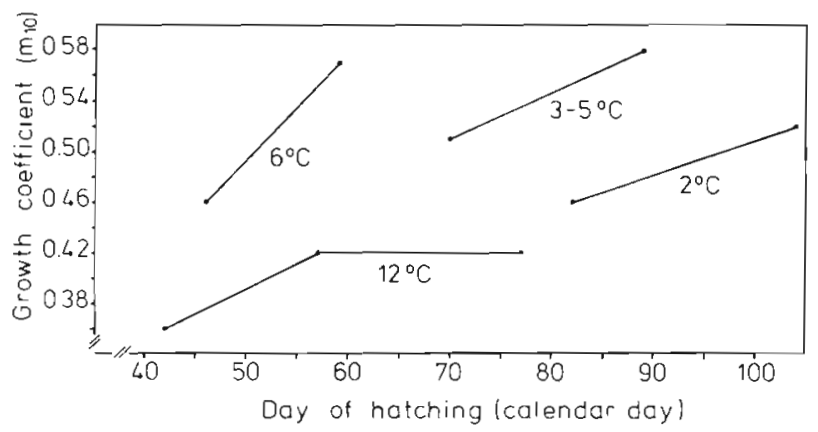

Fig. 3. Hyas araneus. Growth coefficient $\left(\mathrm{m}_{10}\right)$ of zoea I stage in relation to incubation temperature during late embryonic development $\left({ }^{\circ} \mathrm{C}\right)$ and day of hatching. For explanation of $\mathrm{m}_{10}$ see text

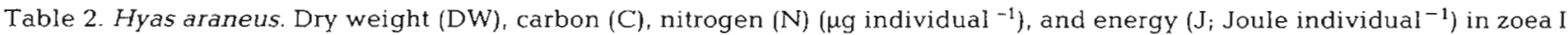
larvae immediately after hatching $(0 \mathrm{~d})$ and after $10 \mathrm{~d}(\overline{\mathrm{x}}$, mean; $\pm 95 \%$ confidence intervals) in relation to day of hatching $(\mathrm{DH}=$ calendar day) and incubation temperature during late embryonic development $\left({ }^{\circ} \mathrm{C}\right)$

\begin{tabular}{|c|c|c|c|c|c|c|c|c|c|c|}
\hline \multirow[b]{2}{*}{$\mathrm{DH}$} & \multirow[b]{2}{*}{${ }^{\circ} \mathrm{C}$} & & \multicolumn{2}{|c|}{$D W$} & \multicolumn{2}{|c|}{$C$} & \multicolumn{2}{|c|}{$\mathrm{N}$} & \multicolumn{2}{|c|}{$\mathrm{J}$} \\
\hline & & & $0 \mathrm{~d}$ & $10 \mathrm{~d}$ & $0 \mathrm{~d}$ & $10 \mathrm{~d}$ & $0 \mathrm{~d}$ & $10 \mathrm{~d}$ & $0 \mathrm{~d}$ & $10 \mathrm{~d}$ \\
\hline 42 & 12 & $\begin{array}{l}\bar{x} \\
\pm\end{array}$ & $\begin{array}{r}61.5 \\
1.0\end{array}$ & $\begin{array}{r}137.9 \\
3.3\end{array}$ & $\begin{array}{r}24.6 \\
0.4\end{array}$ & $\begin{array}{r}55.8 \\
1.9\end{array}$ & $\begin{array}{l}5.5 \\
0.1\end{array}$ & $\begin{array}{r}11.6 \\
0.4\end{array}$ & $\begin{array}{l}0.90 \\
0.02\end{array}$ & $\begin{array}{l}2.05 \\
0.08\end{array}$ \\
\hline 46 & 6 & $\begin{array}{l}\bar{x} \\
\pm\end{array}$ & $\begin{array}{r}61.9 \\
2.0\end{array}$ & $\begin{array}{r}151.6 \\
3.6\end{array}$ & $\begin{array}{r}21.9 \\
0.3\end{array}$ & $\begin{array}{r}59.8 \\
0.8\end{array}$ & $\begin{array}{l}5.2 \\
0.1\end{array}$ & $\begin{array}{r}12.4 \\
0.2\end{array}$ & $\begin{array}{l}0.76 \\
0.02\end{array}$ & $\begin{array}{l}2.17 \\
0.04\end{array}$ \\
\hline 57 & 12 & $\begin{array}{l}\bar{x} \\
\pm\end{array}$ & $\begin{array}{r}66.1 \\
1.5\end{array}$ & $\begin{array}{r}158.6 \\
2.6\end{array}$ & $\begin{array}{r}23.5 \\
0.3\end{array}$ & $\begin{array}{r}61.9 \\
0.7\end{array}$ & $\begin{array}{l}5.4 \\
0.1\end{array}$ & $\begin{array}{r}13.0 \\
0.2\end{array}$ & $\begin{array}{l}0.82 \\
0.01\end{array}$ & $\begin{array}{l}2.24 \\
0.02\end{array}$ \\
\hline 59 & 6 & $\begin{array}{l}\bar{x} \\
\pm\end{array}$ & $\begin{array}{r}65.4 \\
0.5\end{array}$ & $\begin{array}{r}175.8 \\
3.2\end{array}$ & $\begin{array}{r}22.4 \\
0.2\end{array}$ & $\begin{array}{r}75.3 \\
1.6\end{array}$ & $\begin{array}{l}5.5 \\
0.1\end{array}$ & $\begin{array}{r}15.5 \\
0.2\end{array}$ & $\begin{array}{l}0.77 \\
0.01\end{array}$ & $\begin{array}{l}2.84 \\
0.07\end{array}$ \\
\hline 70 & 4 & $\begin{array}{l}\bar{x} \\
\pm\end{array}$ & $\begin{array}{r}56.6 \\
0.8\end{array}$ & $\begin{array}{r}160.2 \\
3.5\end{array}$ & $\begin{array}{r}21.9 \\
0.3\end{array}$ & $\begin{array}{r}68.1 \\
2.3\end{array}$ & $\begin{array}{l}5.5 \\
0.1\end{array}$ & $\begin{array}{r}13.8 \\
0.5\end{array}$ & $\begin{array}{l}0.79 \\
0.02\end{array}$ & $\begin{array}{l}2.56 \\
0.10\end{array}$ \\
\hline 77 & 12 & $\begin{array}{l}\bar{x} \\
\pm\end{array}$ & $\begin{array}{r}59.4 \\
1.2\end{array}$ & $\begin{array}{r}144.1 \\
2.9\end{array}$ & $\begin{array}{r}22.2 \\
0.4\end{array}$ & $\begin{array}{r}57.3 \\
1.2\end{array}$ & $\begin{array}{l}5.2 \\
0.1\end{array}$ & $\begin{array}{r}12.0 \\
0.2\end{array}$ & $\begin{array}{l}0.79 \\
0.02\end{array}$ & $\begin{array}{l}2.09 \\
0.05\end{array}$ \\
\hline 82 & 2 & $\begin{array}{l}\bar{x} \\
\pm\end{array}$ & $\begin{array}{r}63.2 \\
2.1\end{array}$ & $\begin{array}{r}153.4 \\
2.8\end{array}$ & $\begin{array}{r}22.3 \\
0.3\end{array}$ & $\begin{array}{r}61.3 \\
2.2\end{array}$ & $\begin{array}{l}5.5 \\
0.1\end{array}$ & $\begin{array}{r}13.8 \\
0.5\end{array}$ & $\begin{array}{l}0.77 \\
0.01\end{array}$ & $\begin{array}{l}2.24 \\
0.10\end{array}$ \\
\hline 89 & 4 & $\begin{array}{l}\bar{x} \\
\pm\end{array}$ & $\begin{array}{r}63.3 \\
0.7\end{array}$ & $\begin{array}{r}177.6 \\
3.0\end{array}$ & $\begin{array}{r}23.3 \\
0.3\end{array}$ & $\begin{array}{r}79.9 \\
1.3\end{array}$ & $\begin{array}{l}6.3 \\
0.1\end{array}$ & $\begin{array}{r}15.7 \\
0.2\end{array}$ & $\begin{array}{l}0.82 \\
0.01\end{array}$ & $\begin{array}{l}3.09 \\
0.05\end{array}$ \\
\hline 104 & 2 & $\begin{array}{l}\bar{x} \\
\pm\end{array}$ & $\begin{array}{r}61.4 \\
1.0\end{array}$ & $\begin{array}{r}167.6 \\
2.6\end{array}$ & $\begin{array}{r}23.9 \\
0.5\end{array}$ & $\begin{array}{r}74.2 \\
1.6\end{array}$ & $\begin{array}{l}5.7 \\
0.1\end{array}$ & $\begin{array}{r}14.4 \\
0.3\end{array}$ & $\begin{array}{l}0.86 \\
0.02\end{array}$ & $\begin{array}{l}2.84 \\
0.07\end{array}$ \\
\hline
\end{tabular}


during late embryonic development also exerts an influence: after incubation of late embryos at $12^{\circ} \mathrm{C}$, zoea I larvae grow generally at substantially lower rates as opposed to those previously incubated at lower temperatures, i.e. under more natural conditions. Highest initial energy gain was observed in larvae incubated under simulated 'ambient' water temperatures ( 3 to $5{ }^{\circ} \mathrm{C}$; Fig. 3 ).

Biomass accumulated within the first $10 \mathrm{~d}$ of larval life is negatively correlated with the duration of development in the first zoeal stage. Energy is taken as an example in Fig. 4.

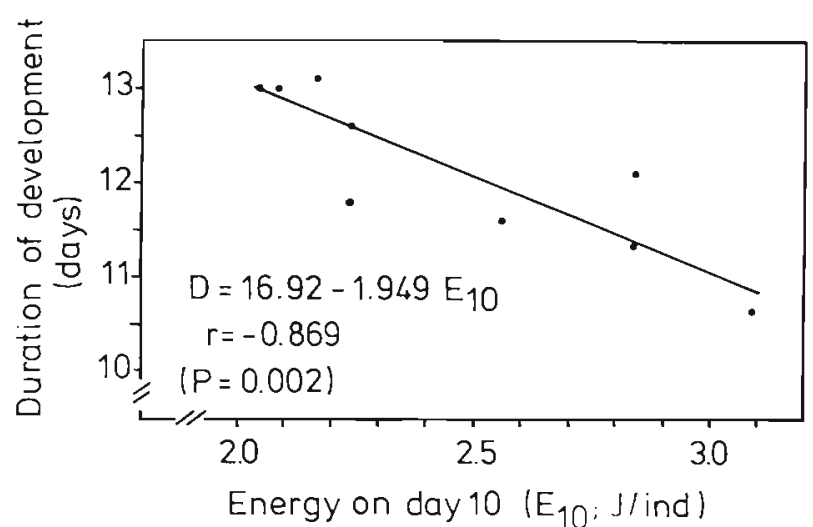

Fig. 4. Hyas araneus. Development time (D) of zoea I stage in relation to larval energy content $10 \mathrm{~d}$ after hatching $\left(\mathrm{E}_{10}\right)$. r, P: see Fig. 1

\section{Variation in juvenile growth}

Growth rate of juvenile crabs was not measured directly, in terms of biomass, but indirectly, as an increase in carapace length. It was not clearly influenced by the time of larval hatching, although this time had an effect on early zoeal growth (see above). Statistically significant relations, however, were found between growth rate and temperature regimen prevailing during late embryonic development: the higher this temperature was, the lower was the rate of juvenile growth (Fig. 5). This holds true also for the whole larval development, as body size in freshly metamorphosed crabs already shows a significantly decreasing tendency with increasing temperature. During later juvenile development these differences in body size increased, and the regression lines became steeper from stage to stage (Fig. 5). Unfortunately, mortality was very high due to a short transitory failure of temperature control in the rearing system, particularly in the $6{ }^{\circ} \mathrm{C}$ group, sothat crab II to IV instars are represented by much lower individual numbers compared to the first instar. The trends shown in Fig. 5 are statistically still highly significant.

Growth rate expressed as percentage of initial carapace length was fairly constant in the first 3 instars in all experimental groups: at each moult there was a ca. 20 to $25 \%$ gain in size. This constancy explains why the absolute differences between the experimental groups become bigger, i.e. the regression lines become steeper from instar to instar (Fig. 5). Variation of size increased during juvenile growth. Overlapping values were observed first between stages II and III.

\section{Variation in juvenile mortality}

Mortality rate in juvenile crabs showed no relation to either previous temperature nor time of hatching. However, many dead crabs tended to deviate in size from the group average (hatch, instar etc.). To examine this observation, carapace lengths in a population of 238 crabs were converted to percentage figures of the mean. Fig. 6 shows that average-sized crabs (99 to $101 \%$ of the mean), and those slightly above the average exhibited the lowest mortality. Unusually small, but also particularly big individuals $(<99 \%$ and $>103 \%$ of the mean) revealed increased mortality. A chi square test (Sachs, 1974 ; p. 379) revealed a statistically significant deviation $(P<0.05)$ from equal distribution of mortality figures between different size classes of the population.

This effect causes a change in population structure: The part of the population surviving to the crab II instar shows a steeper size-frequency distribution pattern (Fig. 6, upper graph), where especially small individuals are less represented than in the original population (crab I).

\section{Interrelations between development and growth}

Analysis of the 1981 data showed that the size of the first crab stage is negatively correlated with the development duration in all larval stages, i.e. slower developing larvae tend to metamorphose to smaller juveniles: the correlation coefficients $(r)$ were -0.19 (zoea I), -0.17 (zoea II), -0.32 (zoeal stages combined), -0.36 (megalopa), and -0.42 (total larval development). All these $r$ values are highly significant ( $\mathrm{df}=302$ in both zoeal stages, and 299 in the megalopa stage and in total larval development).

When the duration of young crabs was plotted against their size in the next instar, again highly significant negative correlations were found:

Development time

in crab I vs. size crab II : $\mathrm{r}=-0.42(\mathrm{df}=211)$

Development time

in crab II vs. size crab III $: r=-0.31(\mathrm{df}=146)$

Development time

in crab III vs. size crab IV : $r=-0.25(\mathrm{df}=123)$ 


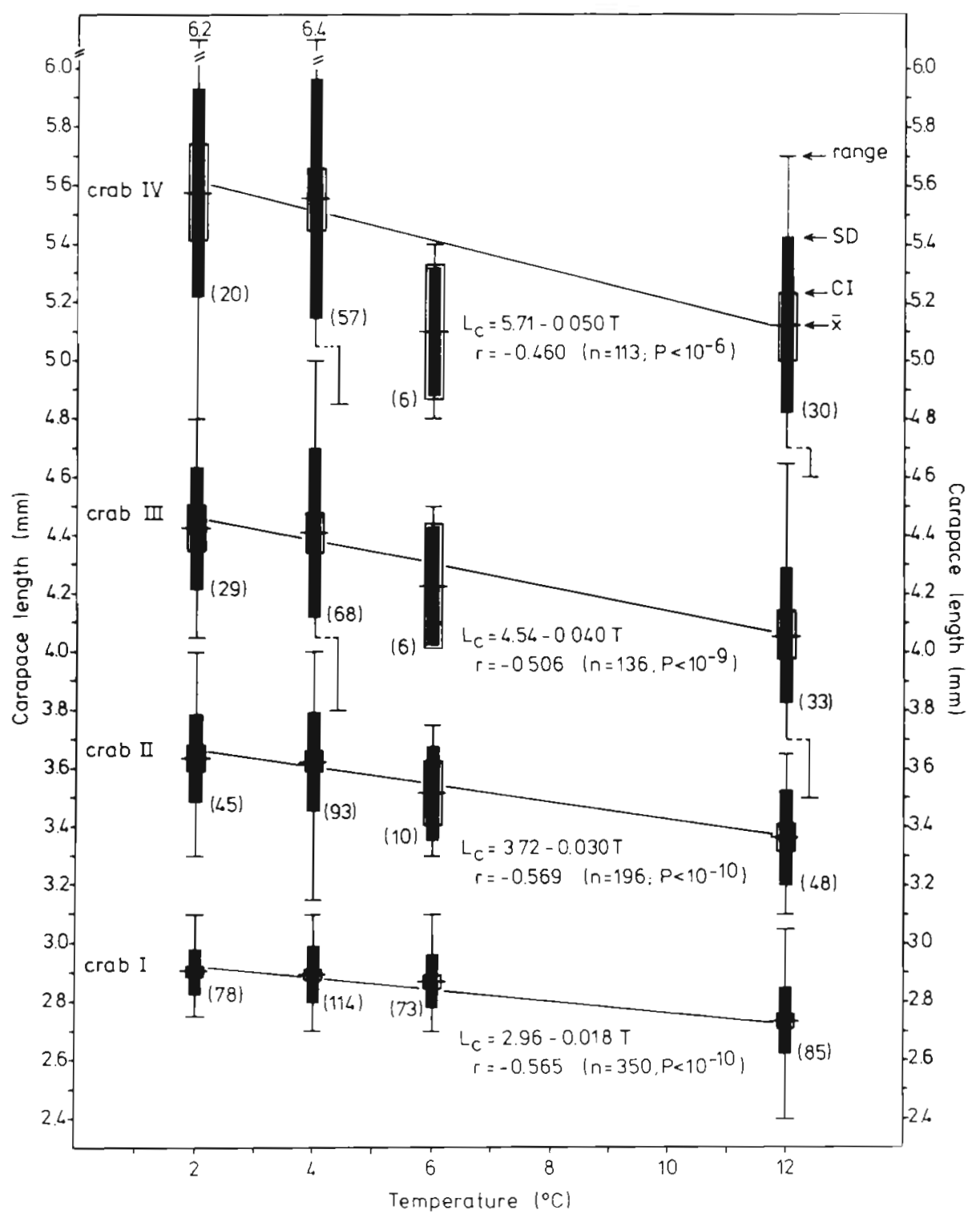

Fig. 5. Hyas araneus. Carapace length $\left(\mathrm{L}_{c}\right)$ of juvenile crab instars $I$ to $I V$ in relation to incubation temperature during late embryonic development $(T)$. $L_{c}$ : mean $(\bar{x}) \pm 95 \%$ confidence intervals (CI), standard deviation (SD), and range; number of measurements (n) in parentheses. $r$, P: see Fig. 1

Variation in both, development duration and carapace size increased and the correlation between these 2 measurements decreased from instar to instar. No more significant correlation was found between development in the crab IV and size of the crab V stage $(\mathrm{r}=-0.15 ; \mathrm{df}=83)$.

\section{DISCUSSION}

\section{Significance of temperature during early life}

Near Helgoland, the natural hatching season of Hyas araneus lasts mainly from February through April, when water temperature is ca. 3 to $6{ }^{\circ} \mathrm{C}$ (Anger, 1983). In this range there is no apparent effect of temperature during late embryonic development on later larval life (Fig. 3). Only at $12{ }^{\circ} \mathrm{C}$ was there a clear negative effect of increased temperature on later larval and postlarval growth (Fig. 3 and 5). This fact is surprising since larvae previously incubated at 2 or $6{ }^{\circ} \mathrm{C}$ develop normally with low mortalities, when transferred to $12{ }^{\circ} \mathrm{C}$ immediately upon hatching and then reared at this temperature. This suggests that a period of low temperature during embryonic development is necessary. Such presumption is supported by further laboratory observations (Anger, unpubl.): in egg batches incu- 


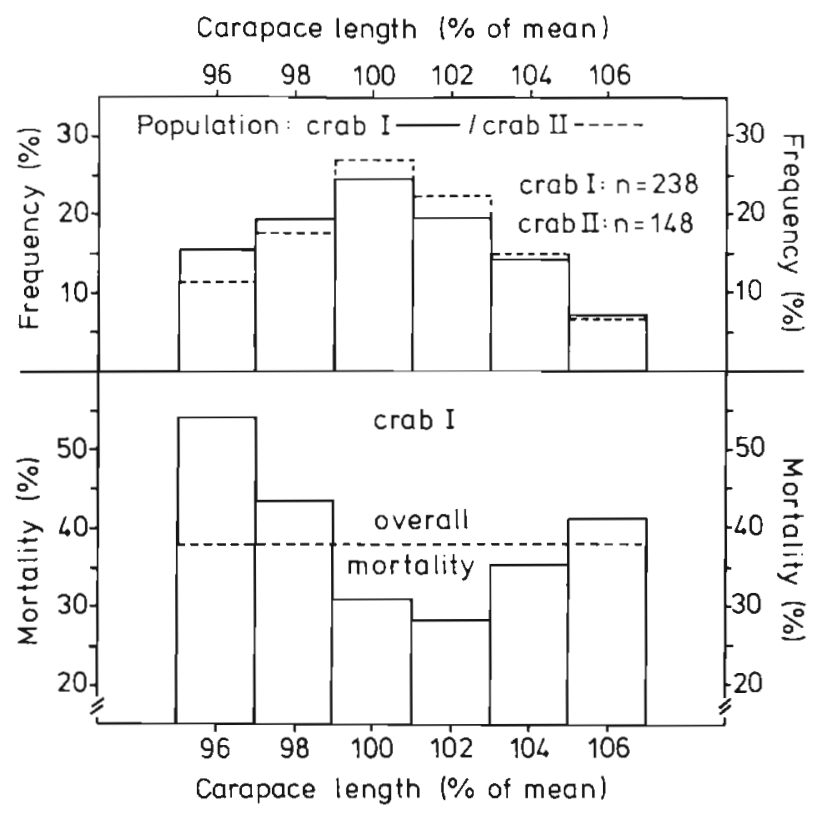

Fig. 6. Hyas araneus. Size-frequency distribution in an experimental population of juvenile crabs, before (crab I) and after moulting (crab II); mortality during crab I instar in relation to carapace length (expressed as \% of the mean value)

bated before hatching for several weeks at $12{ }^{\circ} \mathrm{C}$, hatching rate is low, many larvae are not able to rupture the egg membrane, or they remain in the prezoea stage. This holds also true, though less conspicuously, for very short periods immediately preceding hatching, and even for egg batches that had already successfully begun to hatch at lower temperature, but then were transferred to $12{ }^{\circ} \mathrm{C}$. This indicates that the hatching process too requires low temperatures.

When ovigerous females are kept for some time at $18^{\circ} \mathrm{C}$ they drop their eggs within a few days or weeks. Frequently, this also happens in females maintained at constant $12{ }^{\circ} \mathrm{C}$, but it takes longer (several months). Ovigerous females maintained at constant 2 to $6{ }^{\circ} \mathrm{C}$ or at simulated ambient temperatures (cf. Anger, 1983) release viable larvae in most cases after ca. 1 yr.

Our observations concerning the role of temperature during embryonic development fit well with the results and hypotheses presented by Wear (1974): in 4 species, among them in Hyas coarctatus, he found a diapause period, i.e. embryonic development could not be shortened significantly by raising the water temperature. He suggested that diapause may be an adaptation to the availability of planktonic food for larvae. He also observed that egg survival and larval viability are reduced with increasing temperature, especially in species having large eggs. $H$. araneus definitely belongs to the group of brachyuran crabs with the largest eggs. Like $H$. coarctatus it has probably also a diapause period during its embryonic development and, corresponding to its subarctic distribution (Christiansen, 1969, 1982), its reproduction and development is adapted to cold-water temperatures. The existence of a diapause in $H$. araneus is suggested by unpublished observations showing that increased temperature shortened the duration of embryonic development to a much less degree than larval development (cf. Anger, 1983).

\section{Seasonal effects}

Fig. 1 to 3 indicate the existence of seasonal effects on larval and postlarval life: larvae hatching later during winter or spring exhibited higher growth (energy accumulation) rates (Fig. 3), and tended to develop faster in all larval and juvenile instars (Fig. 1 and 2). These effects may disappear toward the end of the hatching season (Fig. 2) and, under natural conditions (i.e. increasing water temperatures), they may in part be compensated by the above effects of temperature. Since there was no or only little temperature change during late embryonic development, and the larvae were reared under identical conditions, it is very difficult to explain these seasonal effects on the basis of our present knowledge. Possibly, there are seasonal differences in the nutrition of the females during oogenesis affecting the storage of yolk reserves in the oocytes.

\section{Natural variability}

Besides seasonal and temperature-induced variation there is always variation from hatch to hatch (genetic differences and/or those caused by different conditions during oogenesis) and within a single egg batch. The latter is as difficult to explain as seasonal effects. There might be differences in oxygen availability in different layers of the egg mass. This is suggested by the fact that the last eggs in a batch, i.e. those situated in the most proximal (innermost) part, are not kept until all larvae finally leave the egg membrane, but they are eventually dropped by the female without further hatching success.

Genetic differences among sibling larvae treated identically tend to persist throughout larval and juvenile development: most of the larvae that require more time than average to complete zoea I development stay also longer in the zoea II stage, and they metamorphose to smaller crabs. These crabs, again, tend to develop at lower speed and to stay smaller than average-sized siblings also in later instars. Since relative growth rates (expressed as \% of premoult body size) are fairly constant, this means increasing absolute variation in body size within a population of siblings 
(Fig. 5). This effect is partly compensated by differential mortality eliminating mainly the smallest, but also (to a lesser degree) the largest individuals in the population (Fig. 6).

\section{CONCLUSIONS}

The present study reports statistical interrelations between various measurements of development and growth in larval and juvenile spider crab, rather than analyses and explains them. No direct influences by environmental factors were investigated, but some likely sources of 'background noise' were identified (Fig. 7) indicating the directions of presumable effects.

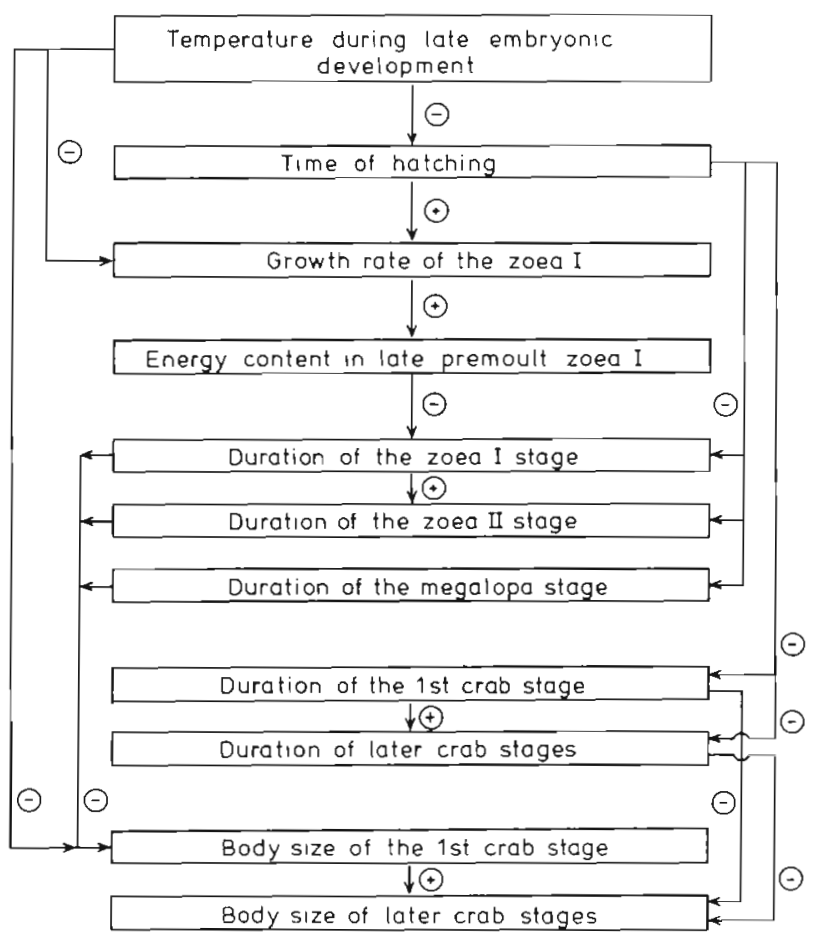

Fig. 7. Hyas araneus. Interrelations between different measurements of larval and postlarval development and growth, in part influenced by the temperature during late embryonic development and by seasonal effects (time of hatching). Direction of effects indicated by arrows and signs of correlation

Our findings may be summarized as follows: variation in development and growth rate is influenced by temperature during late embryogenesis, by seasonal factors (time of hatching), and by natural (mainly genetic) variability. Increased incubation temperature shortens late embryonic development, lowers early zoeal biomass growth rate, and causes development to smaller juveniles (negative signs of correlation in Fig. 7). Delayed time of hatching is followed by increased zoeal growth and decreased larval and postlarval development durations. Increased initial growth rates lead to higher premoult biomass and energy in the zoea I and to shortened larval development. The latter is followed by metamorphosis to larger juveniles. If the first crab instar is particularly large, also the following juvenile instars will be larger than average. Body size in juvenile spider crabs is negatively correlated with duration of instar development, i.e. individuals with delayed intermoult periods tend to grow less with each moult.

Further knowledge of such tendencies and effects should improve understanding and predictability of crustacean growth both in basic scientific (ecological) and applied (aquaculture) research.

Acknowledgements. This research was supported by 'Bundesministerium für Forschung und Technologie', Bonn (Grant No. MFU-0502/7). Ms. B. Lämmel made the drawings and Dr. M. Rieper corrected the manuscript.

\section{LITERATURE CITED}

Anger, K., Dawirs, R. R. (1981). Influence of starvation on the larval development of Hyas araneus (Decapoda: Majidae). Helgoländer Meeresunters. 34: 287-311

Anger, K., Dawirs, R. R. (1982). Elemental composition (C, N, $\mathrm{H})$ and energy in growing and starving larvae of Hyas araneus (Decapoda: Majidae). Fish. Bull. U. S. 80: $419-433$

Anger, K. (1983). Temperature and the larval development of Hyas araneus L. (Decapoda: Majidae); extrapolation of láboratory data to field conditions. J. exp. mar. Biol. Ecol. 69: 203-215

Anger, K., Laasch, N., Püschel, C., Schorn, F. (1983). Changes in biomass and chemical composition of spider crab (Hyas araneus) larvae reared in the laboratory. Mar. Ecol. Prog. Ser. 12: 91-101

Christiansen, M. E. (1969). Crustacea Decapoda Brachyura Marine invertebrates of Scandinavia, No. 2. Universitetsforlaget, Oslo, p. 1-143

Christiansen, M. E. (1982). A review of the distribution of Crustacea (Decapoda: Brachyura) in the Northeast Atlantic. Quad. Lab. Tecnol. Pesca 3: 347-354

Dawirs, R. R. (1979). Effects of temperature and salinity on larval development of Pagurus bernhardus (Decapoda, Paguridae). Mar. Ecol. Prog. Ser. 1: 323-329

Dawirs, R. R. (1981). Elemental composition (C, N, H) and energy in the development of Pagurus bernhardus (Decapoda: Paguridae) megalopa. Mar. Biol. 64: 117-123

Dawirs, R. R. (1982a). Laboruntersuchungen zur larvalen Entwicklung von Carcinus maenas L. (Decapoda: Portunidae) und Pagurus bernhardus L. (Decapoda: Paguridae). Dissertation, Universität Kiel

Dawirs, R. R. (1982b). Methodical aspects of rearing decapod larvae, Pagurus bernhardus (Paguridae) and Carcinus maenas (Portunidae). Helgoländer Meeresunters. 35: $439-464$

Dawirs, R. R. (1983). Respiration, energy balance and development during growth and starvation of Carcinus maenas L. larvae (Decapoda: Portunidae). J. exp. mar. Biol. Ecol. 69: 105-128

Lang, W. H., Young, A. M. (1977). The larval development of Clibanarius vittatus (Bosc) (Crustacea: Decapoda; 
Diogenidae) reared in the laboratory. Biol. Bull. mar. biol. Lab., Woods Hole 152: 84-104

Pandian, T. J. (1970). Yolk utilization and hatching time in the Canadian lobster Homarus americanus. Mar. Biol. 7 : $249-254$

Pandian, T. J., Schumann, K.-H. (1967). Chemical composition and caloric content of egg and zoea of the hermit crab Eupagurus bernhardus. Helgoländer wiss. Meeresunters. 16: $225-230$

Pandian, T. J., Katre, S. (1972). Effect of hatching time on larval mortality and survival of the prawn, Macrobrachium idae. Mar. Biol. 13: 330-337

Sachs, L. (1974). Angewandte Statistik, 4 th ed. Springer Verlag, Berlin

Salonen, K., Sarvala, J., Hakala, I., Viljanen, M.-L. (1976). The relation of energy and organic carbon in aquatic invertebrates. Limnol. Oceangr. 21: 724-730

Sastry, A. N., Sandra, L., Vargo, S. L. (1977). Variation in physiological responses of crustacean larvae to temperature. In: Vernberg, F. J., Calabrese, A., Thurberg, F. P., Vernberg, W. B. (ed.) Physiological responses of marine biota to pollutants. Academic Press, New York, p. 401-423

Schriever, G. (1976). Hyas araneus Linne und Stenorhynchus seticornis Herbst. Zur Biologie, Okologie und Ethologie der Familie Majidae (Crustacea: Brachyura). Thesis, Universität Kiel

Wear, R. (1974). Incubation in British Decapod Crustacea and the effect of temperature on the rate of success of embryonic development. J. mar. biol. Ass. U. K. 54: 745-762

Wilson, K. A. (1980). Studies on decapod crustacea from the Indian River region of Florida. XV. The larval development under laboratory conditions of Euchirograpsus americanus A. Milne Edwards, 1880 (Crustacea, Decapoda: Grapsidae) with notes on grapsid subfamilial larval characters. Bull. mar. Sci. 30: 756-775

This paper was presented by Professor H.-P. Bulnheim; it was accepted for printing on September 27, 1983 